\title{
DEMAND FORECASTING: A COMPARISON BETWEEN THE HOLT-WINTERS, TREND ANALYSIS AND DECOMPOSITION MODELS
}

\author{
Güzin Tirkeș, Cenk Güray, Neş'e Çelebi
}

Preliminary communication

In food production industry, forecasting the timing of demands is crucial in planning production scheduling to satisfy customer needs on time. In the literature, several statistical models have been used in demand forecasting in Food and Beverage (F\&B) industry and the choice of the most suitable forecasting model remains a central concern. In this context, this article aims to compare the performances between Trend Analysis, Decomposition and Holt-Winters (HW) models for the prediction of a time series formed by a group of jam and sherbet product demands. Data comprised the series of monthly sales from January 2013 to December 2014 obtained from a private company. As performance measures, metric analysis of the Mean Absolute Percentage Error (MAPE) is used. In this study, the HW and Decomposition models obtained better results regarding the performance metrics.

Keywords: decomposition; demand forecasting; food industry; Holt-Winters; time series

Predviđanje potražnje: usporedba između Holt-Winters modela, analize trenda i modela dekompozicije

Prethodno priopćenje U industriji proizvodnje hrane, predviđanje vremena potražnje je bitno u planiranju proizvodnje kako bi se na vrijeme zadovoljile potrebe kupaca. U literaturi se koristi nekoliko statističkih modela za planiranje potražnje u industriji hrane i pića, a izbor najpogodnijeg modela od osnovnog je značaja. U tom kontekstu cilj je ovoga rada usporedba primjenljivosti modela analize trenda, dekompozicije i Holt-Winters (HW) modela za predviđanje vremenskih serija u potražnji đema i voćnih sokova. Obrađeni su podaci jednog privatnog poduzeća od siječnja 2013 do prosinca 2014. Uspješnost se odredila metričkom analizom Mean Absolute Percentage Error (MAPE) (srednji apsolutni postotak greške). U ovom su radu najbolji rezultati u planiranju potražnje postignuti modelima Holt-Winters i dekompozicije.

Ključne riječi: dekompozicija; industrija hrane; Holt-Winters; predviđanje potražnje; vremenska serija

\section{Introduction}

In Food and Beverage (F\&B) industry, a great deal of research has been undertaken in recent times on facility capacity expansion and production planning problems under deterministic and stochastic demand in the literature. However, markets worldwide are strongly affected by seasonality and changing trends. These difficulties result in problems such as resource allocation, inventory cost, unexpected variations in supply, demand and operation timings and increase in competitive pressure in business environment in planning and optimization. Most of the companies operate in the market with volatility. The leading large companies understand the importance of production planning and optimization and apply integrated process solutions. The use of advanced manufacturing technology and specific mathematical models specialized in production planning, scheduling and handling uncertainty allows F\&B manufacturers to increase production and become increasingly streamlined and efficient in the sector. However, only a small portion of this work directly addresses the issues faced by the F\&B industry especially in small and medium size enterprises. In F\&B industry, forecasting the timing of demands is crucial in planning production scheduling to satisfy customer needs on time.

There are different forecasting techniques including trend and seasonality and several comparative studies in the food industry in the literature. The most widely used methods are: Winter's smoothing method, Holt method, Time series regression, Decomposition, and ARIMA models. However, the findings do not suggest what conditions make a method better than the other. The present article aims to make a comparison between Trend
Analysis, Decomposition and the Holt-Winters (HW) model.

There are some strengths and weaknesses of the aforementioned models in the literature. Trend analysis model is simple and easy to use. However, it is not always applicable for long-term time series. In such cases there have been several trends and the data set should not be applicable to seasonal and cyclical data patterns. Decomposition model is able to examine the data set in components named as trend, seasonality, cyclic and random. However on the other hand, it faces some difficulties in decomposing trend and seasonality when a few seasonal cycles exist in a series, thus it would perform more successfully if the amount of historical data was high. The HW model is simple and can give precise forecasting results comparable to the results of more complex techniques. This method is prevalent, simple to utilize and generally works well in practical applications. Dependence on historical data is low and depends on all previous values, with the most weight given to the most recent values. It is important to choose the correct model to reach the desired coverage of future values.

In the literature there are some applications regarding these models (see Tab. 1). In 2001, Carauna, analyzed carbonated soft drink market by building a forecasting model utilizing seasonal regression [1]. Lon-Mu et al. used fast-food franchise as a case in order to illustrate how data mining can be applied to such time series using Box-Jenkins seasonal ARIMA models. They used data in daily intervals and aimed to forecast daily demand to facilitate a better inventory management. They used 365 days of data for analysis and 42 days of data for comparison of forecast performance. Results of their study showed that they obtained appropriate models for a time series [2]. Wassana et al. developed a statistical 
model for long-term forecasting sparkling beverages sales by using monthly sales revenue of 4 years data by using Lee-Carter forecasting approach and exponential smoothing HW with additive seasonality method. They found that Lee-Carter model with HW method produced an excellent fit and gave sensible estimates in long-term sales forecasting [3]. In 2014 Veiga et al. compared the performances of ARIMA and HW models for the prediction of a time series formed by a group of perishable dairy products. They used 8 years of sales data. As evaluation metric, they used MAPE and Theil inequality index (U-Theil). Results showed that HW obtained better results regarding the performance [4]. Barbosa et al. analysed and forecast the sales demand in pasta and sausage production company in order to improve the short to medium term production planning. They used HW model and $\mathrm{ABC}$ ranking analysis [5]. Arunraj and Ahrens developed a forecasting model using seasonal ARIMA model in order to forecast daily sales of perishable food [6].

Table 1 Forecasting methods in the literature

\begin{tabular}{|c|c|c|c|}
\hline Authors & Area & $\begin{array}{c}\text { Forecasting } \\
\text { Methodology }\end{array}$ & $\begin{array}{c}\text { Forecasting } \\
\text { Period }\end{array}$ \\
\hline $\begin{array}{c}\text { Carauna and } \\
\text { Albert, 2001 }\end{array}$ & $\begin{array}{c}\text { Carbonated } \\
\text { soft drink }\end{array}$ & $\begin{array}{c}\text { Seasonal } \\
\text { Regression }\end{array}$ & Short-term \\
\hline $\begin{array}{c}\text { Lon-Mu } \\
\text { et al., 2001 }\end{array}$ & $\begin{array}{c}\text { Fast food } \\
\text { franchise }\end{array}$ & $\begin{array}{c}\text { Box-Jenkins, } \\
\text { ARIMA }\end{array}$ & Short-term \\
\hline $\begin{array}{c}\text { Wassana } \\
\text { et al., 2011 }\end{array}$ & $\begin{array}{c}\text { Sparkling } \\
\text { beverages }\end{array}$ & Lee Carter, HW & Long-term \\
\hline $\begin{array}{c}\text { Veiga } \\
\text { et al., 2014 }\end{array}$ & $\begin{array}{c}\text { Dairy food } \\
\text { products }\end{array}$ & HW, ARIMA & Long-term \\
\hline $\begin{array}{c}\text { Barbosa } \\
\text { et. al., 2015 }\end{array}$ & $\begin{array}{c}\text { Pasta and } \\
\text { Sausage }\end{array}$ & HW & Medium-term \\
\hline $\begin{array}{c}\text { Arunraj and } \\
\text { Ahrens, 2015 }\end{array}$ & $\begin{array}{c}\text { Perishable } \\
\text { Food }\end{array}$ & ARIMA & Short-term \\
\hline
\end{tabular}

All of these studies show that any prediction model can be considered universally the best [7]. Literature reveals that there is not any study in production planning and scheduling and optimization in F\&B industry comparing Trend analysis, Decomposition and HW methods. This study presents the results by comparing demand forecasting methods using Trend analysis, Decomposition and HW methods in production scheduling problem of a real world multi-stage and multiline sherbet and jam production company producing multiple products for both retail and bulk sale sharing a limited capacity when demands are uncertain.

\section{Theoretical framework}

The review will be limited to the methodologies used in this work, therefore, three models of demand forecasting are described: Trend Analysis, Decomposition and triple exponential smoothing of the HW method, as well as the performance metrics of accuracy of demand forecasting, which involves only the MAPE accuracy measure. These three methods were selected as they can be partially adapted for the data sets, where trend, seasonal and cyclic effects can be observed together. Thus, at the end, these three methods can check out all the possible models that can be applicable to the data set.

\subsection{Trend analysis method}

Trend analysis fits a general trend model to time series data and provides forecasts. This method is used when there is no seasonal component in the series. There are two types of Trend analysis; linear trend and nonlinear trend analysis.

Linear trend is a function described as a straight line along several points of time series value in time series data graph. Linear trend has a common formula as given in Eq. (1):

$T_{t}=a+b Y_{t}$

where $T_{t}$ is a trend value of period $t, a$ is a constant of trend value at base period, $b$ represents coefficient of trend line direction, $Y_{t}$ is an independent variable. The most commonly used method to make Trend analysis is least squares method which finds the coefficient values of the trend equation ( $a$ and $b$ ) by minimizing mean of squared error (MSE) [8].

The formula in the following Eq. (2) and Eq. (3) as given below:

$b=\frac{n \sum Y_{t} T_{t}-\sum Y_{t} \sum T_{t}}{n \sum Y_{t}^{2}-\sum\left(Y_{t}\right)^{2}}$

$a=\bar{Y}_{t}-b \bar{T}_{t}$

In this study, linear trend analysis is applied.

\subsection{Decomposition method}

Decomposition methods are based on an analysis of the individual components of a time series. In Decomposition, each component strength, is estimated separately and then substituted into a model that explains the behaviour of the time series and it is easy to understand. The decomposition of time series divides a time series into five components: mean, long-range trend, seasonality, cycle, and randomness. There are two decomposition methods: multiplicative and additive. In multiplicative model

Value $=($ Mean $) \times($ Trend $) \times($ Seasonality $) \times($ Cycle $) \times$ (Random).

If the data set has seasonality, Decomposition methods can provide additional information on trend and cycle.

The basic Decomposition method consisting of estimating the five components of the model is given in Eq. (4).

$Y_{t}=\operatorname{Mean}\left(T_{t} S_{t} C_{t} I_{t}\right)$

These variables are defined as follows: $Y_{t}$ represents the value of the time series at time $t, T_{t}$ denotes trend at time $t, S_{t}$ is the seasonal component at time $t, C_{t}$ is cyclical component at time $t$ and $I_{t}$ is irregular component at time $t$ [9]. 
In additive decomposition, a time series is modelled as the sum of the trend, seasonal effect, cyclical effect, and irregular effects. This is shown in the following Eq. (5):

$$
Y_{t}=T_{t}+S_{t}+C_{t}+I_{t}
$$

The additive decomposition method is more proper when the regular elements have a tendency to be unfaltering starting with one year then onto the next.

\subsection{Holt-Winters method}

HW Model was first proposed in the early 1960s and is an extension of exponential smoothing method. All data values in a series contribute to the calculation of the prediction model $[10,11]$. This method is used when there is trend and seasonality in the data set.

In general, it can be said that the HW technique is a complex expansion of the exponential smoothing method, since it sums up this approach to manage trend and seasonality. Makridakis et al. described exponential smoothing as a weighted moving average of recent time series and it required a large number of observations [9].

If the smoothed series is denoted by $S_{t}, \alpha$ denotes the smoothing parameter, the exponential $\mathrm{S}$ smoothing constant is between, $0<\alpha<1$.

The smoothed series is given by the Eq. (6):

$S_{t}=\alpha y_{t}+(1-\alpha) S_{t-1}$

where $S_{1}=y_{1}$.

It can be shown that:

$$
S_{t}=\alpha y_{t}+(1-\alpha) y_{t-1}+\alpha(1-\alpha)^{2} y_{t-2}+\ldots+(1-\alpha)^{\mathrm{t}-1} y_{1}
$$

According to Eq. (7) the smoothed series depends on all past values, with the most weight given to the latest values.

Exponential smoothing is not appropriate for the seasonal data that include a cycle or a trend. However, the HW model uses a modified form of exponential smoothing. It applies three exponential smoothing formulae to the series which is called "Triple Exponential Smoothing". Firstly, the mean is smoothed to give a local average value for the series. Secondly, the trend is smoothed and lastly each seasonal sub-series is smoothed separately to give a seasonal estimate for each season. The exponential smoothing formula is applied to a series with a trend and constant seasonal component using the HW additive and multiplicative methods. The additive method is preferred when the seasonal variations are roughly constant through the series, while the multiplicative method is preferred when the seasonal variations are changing proportionally to the level of the series. This study will be applied only to the HW additive model.

Let's estimate $a_{t}$ is the smoothed estimate of the level at time $t, b_{t}$ is the smoothed estimate of the change in the trend value at time $t, s_{t}$ is the smoothed estimate of the appropriate seasonal component at $t$.
In Additive method:

$$
\begin{aligned}
& a_{t}=\alpha\left(Y_{t}-s_{t-p}\right)+(1-\alpha)\left(a_{t-1}+b_{t-1}\right) \\
& b_{t}=\beta\left(a_{t}-a_{t-1}\right)+(1-\beta) b_{t-1} \\
& s_{t}=\gamma\left(Y_{t}-a_{t}\right)+(1-\gamma) s_{t-p}
\end{aligned}
$$

where: $\alpha, \beta$ and $\gamma$ are the smoothing parameters, $a_{t}$ is the smoothed level at time $t$ as given in Eq. (8), $b_{t}$ is the change in the trend at time $t$ as in Eq. (9), $s_{t}$ is the seasonal smoothing parameter at time $t$ and $p$ is the number of seasons per year as in Eq. (10).

The HW algorithm requires starting values as given below Eq. (11), Eq. (12) and Eq. (13).

$$
\begin{aligned}
& a_{p}=\frac{1}{p}\left(Y_{1}+Y_{2}+\ldots+Y_{p}\right) \\
& b_{p}=\frac{1}{p}\left[\frac{Y_{p+1}-Y_{1}}{p}+\frac{Y_{p+2}-Y_{2}}{p}+\ldots+\frac{Y_{p+p}-Y_{p}}{p}\right] \\
& s_{1}=Y_{1}-a_{p}, s_{2}=Y_{2}-a_{p}, \ldots, s_{p}=Y_{p}-a_{p} .
\end{aligned}
$$

The HW forecasts are then calculated using the latest estimations from the appropriate exponential smoothing that has been applied to the series. So we have our forecast for time period $T+\tau$ :

$$
\hat{y}_{T+\tau}=a_{T}+\tau b_{T}+s_{T}
$$

where: $a_{T}$ is the smoothed estimate of the level at time $T$, $b_{T}$ is the smoothed estimate of the change in the trend value at time $T, s_{T}$ is the smoothed estimate of the appropriate seasonal component at $T$ as given in Eq. (14) [12].

Multiplicative model is used when the data exhibit multiplicative seasonality.

The exponential smoothing formulas applied to a series using HW Multiplicative models are given in Eq. (15), Eq. (16) and Eq. (17).

$$
\begin{aligned}
& a_{t}=\alpha \frac{Y_{t}}{s_{t-p}}+(1-\alpha)\left(a_{t-1}+b_{t-1}\right) \\
& b_{t}=\beta\left(a_{t}-a_{t-1}\right)+(1-\beta) b_{t-1} \\
& s_{t}=\gamma \frac{Y_{t}}{a_{t}}+(1-\gamma) s_{t-p}
\end{aligned}
$$

The initialising values for the additive model are as follows, except Eq. (18):

$s_{1}=\frac{Y_{1}}{a_{p}}, s_{2}=\frac{Y_{2}}{a_{p}}, \ldots, \quad s_{p}=\frac{Y_{p}}{a_{p}}$

So we have our prediction for time period $T+\tau$ given in Eq. (19):

$\hat{y}_{T+\tau}=\left(a_{T}+\tau b_{T}\right) s_{T}$ 
After the model is specified, its performance characteristics should be verified or validated by comparing its forecasts with historical data using accuracy measures.

\subsection{Measuring accuracy of forecasting methods}

Baker pointed out that traditional error measures, such as mean square error, do not provide a reliable basis for comparison of methods. There are numerous ways in which the accuracy of a forecasting method is assessed. Hyndman divided forecast error metrics as the mean absolute error (MAE or MAD), percentage-error (MAPE), relative-error and scale free error metrics [13].

For comparisons utilizing a small set of series, it is desirable, likewise, to control level of difficulty in forecasting. Therefore, as a measure of fitting and forecast accuracy of every model we compute the MAPE accuracy measure in this study.

\subsubsection{MAPE}

MAPE evaluation metric is used when the series have a large amount of values being close or equal to zero. It is less sensitive to outliers and can be used to compare forecasting methods on a single series, as well as forecasting accuracy between series. The MAPE is scale dependent. MAPE can be expressed as the following Eq. (20) and Eq. (21):

The percentage error is given by:

$e_{t}=A_{t}-F_{t}$

When simplifying the forecasting error;

$$
p_{t}=100 \frac{e_{t}}{A_{t}}
$$

$$
\mathrm{MAPE}=\operatorname{mean}\left(\left|p_{t}\right|\right)
$$

where $A_{t}$ equals the actual value, $F_{t}$ equals the fitted value, and $n$ equals the number of observations [14].

\section{Methodology}

In this study, a time series model for long term forecasting is developed by obtaining monthly sales data from a sherbet and jam company "Tarihi Yudumla" from January 2013 to December 2014. The examination was mainly quantitative, in accordance with the object of study.

Trend analysis, Decomposition and HW methods are compared and the model that had the best fit to the data set is adapted in order to predict 2015 demand. As performance measures, the MAPE ratio is used as evaluation metric. The selected product group represents approximately $70 \%$ of the total sales of the company to one of its customers.

\section{$4 \quad$ Results and analysis}

The biggest customer of Tarihi Yudumla will be referred to as "Company $\mathrm{X}$ " in the rest of the study. According to the total production amount and sales results of the company between the years 2013-2015, it is clear that for the jam group (blueberry jam, raspberry jam, black mulberry jam) $67 \%$, for the berry sherbet group (black mulberry sherbet, blueberry sherbet, red currant sherbet) $62.7 \%$, and for lemonade $74.6 \%$ of the total sales are received by Company $\mathrm{X}$. The sales quantity percentage is significantly high. Monthly demand of Company $\mathrm{X}$ directs the production planning process in Tarihi Yudumla.

In production planning and scheduling process, the company must decide what to produce and in what amount because ordering procedure of Company $\mathrm{X}$ is not very systematic. In different time periods Company $\mathrm{X}$ sends its current stock quantity and daily sales potential form to the company and according to this information, company plans its production. A sample mail order form is given in Tab. 2 "Product Type" column identifies the aforementioned product. Second column "Stock (kg)" informs their stock level in kilograms in the given date. "Daily Sales (kg)" column gives their daily potential sale and "Remaining Stock (day)" column represents for how many days their inventory is sufficient.

Table 2 A sample mail order form indicating stock position of

\begin{tabular}{|c|c|c|c|}
\hline \multicolumn{4}{|l|}{ 22.04.14 Dated Mail Order } \\
\hline Product Type & $\begin{array}{c}\text { Stock } \\
(\mathrm{kg})\end{array}$ & $\begin{array}{l}\text { Daily } \\
\text { sales } \\
(\mathrm{kg})\end{array}$ & $\begin{array}{c}\text { Remaining } \\
\text { stocks } \\
\text { (days) }\end{array}$ \\
\hline Lemonade & 2790 & 134 & 21 \\
\hline Black Mulberry Sherbet & 494 & 37 & 13 \\
\hline Blueberry Sherbet & 372 & 31 & 12 \\
\hline Red Currant Sherbet & 924 & 20 & 46 \\
\hline Raspberry+Black Mulberry Jam & 450 & 26 & 17 \\
\hline Raspberry+Blueberry Jam & 319 & 6 & 54 \\
\hline Black Mulberry Jam & 113 & 3 & 35 \\
\hline
\end{tabular}
Company X

Demand analysis is conducted in order to identify trend and seasonality in the data for two years. Tab. 3 represents raw demand data for two years.

\begin{tabular}{|l|c|c|c|}
\multicolumn{4}{|c}{ Table 3 Raw demand data of two years } \\
\begin{tabular}{|l|c|c|c|}
\hline & Lemonade & Sherbet group & Jam group \\
\hline January & 0 & 2592 & 1359 \\
\hline February & 1167 & 3920 & 1970 \\
\hline March & 7867 & 2928 & 1991 \\
\hline April & 15093 & 6259 & 1556 \\
\hline May & 17107 & 7674 & 1828 \\
\hline June & 24267 & 9828 & 2119 \\
\hline July & 26920 & 6444 & 733 \\
\hline August & 26405 & 7504 & 759 \\
\hline September & 17295 & 3896 & 1098 \\
\hline October & 933 & 1588 & 1067 \\
\hline November & 500 & 1800 & 1028 \\
\hline December & 0 & 1744 & 678 \\
\hline
\end{tabular}
\end{tabular}

Two years statistical analysis of product demands is given in Fig. 1. In order to display trends over time (months) line chart is used. Seasonality in demand and trend can be seen from the graph. 
In order to better observe the possible presence of seasonality in the series, season charts were created by using the years 2013, 2014 and 2015 average monthly sales. Fig. 2 graphically shows monthly average sales of lemonade for three years.

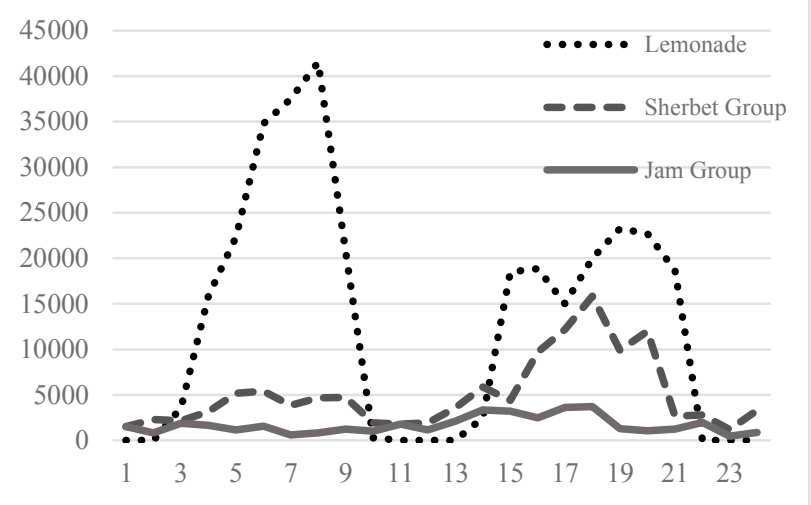

Figure 1 Demand of products in 2013-2015

Fig. 2 shows that lemonade sales are at the lowest level in January and February and increase regularly until July, and reach peak sales in July.

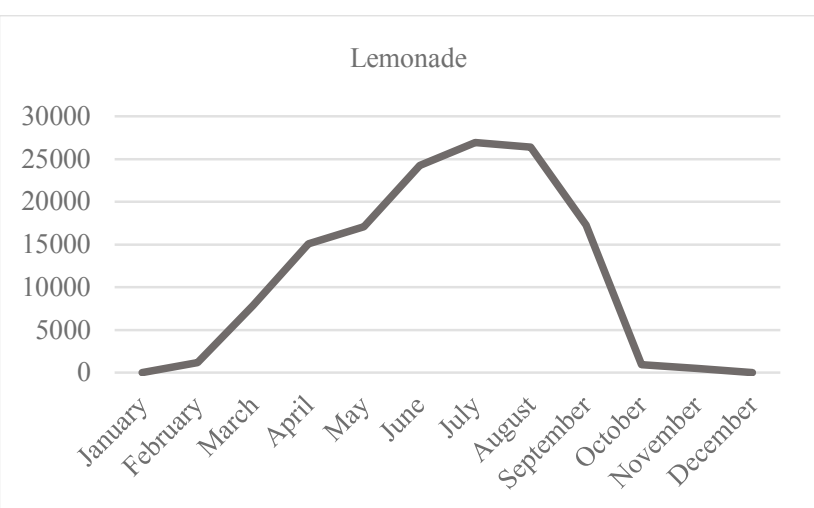

Figure 2 Average sales of Lemonade between 2013-2015

Fig. 3 demonstrates average sales of berry sherbet group. Graph shows that sales are stagnant in winter season and increase in April, reach peak sales in June then decrease until October, and reach the lowest level in December.

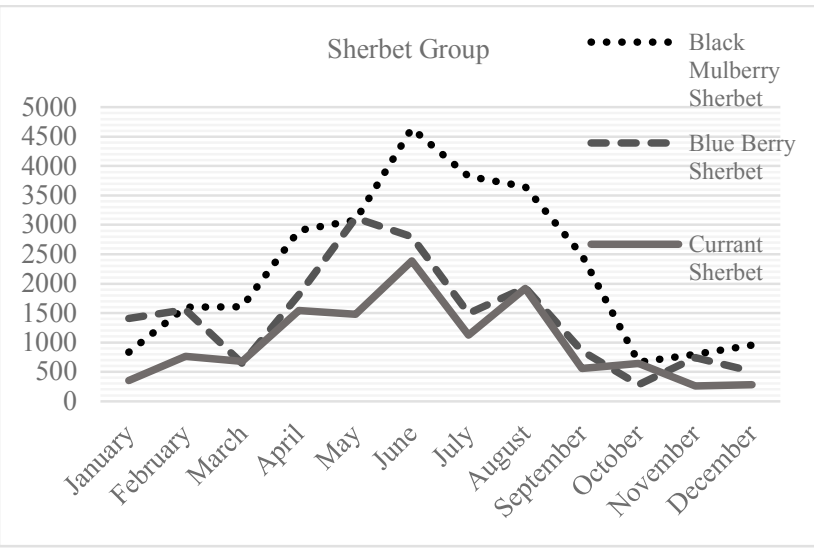

Figure 3 Average sales of Sherbet group between years 2013-2015
Fig. 4 represents jam sales in years between 20132015. Blue berry jam sales are stable during the whole year. Black mulberry jam sales are high in winter season and the direct opposite raspberry jam sales are high in summer season. However, sales of total jam spread over the whole year.

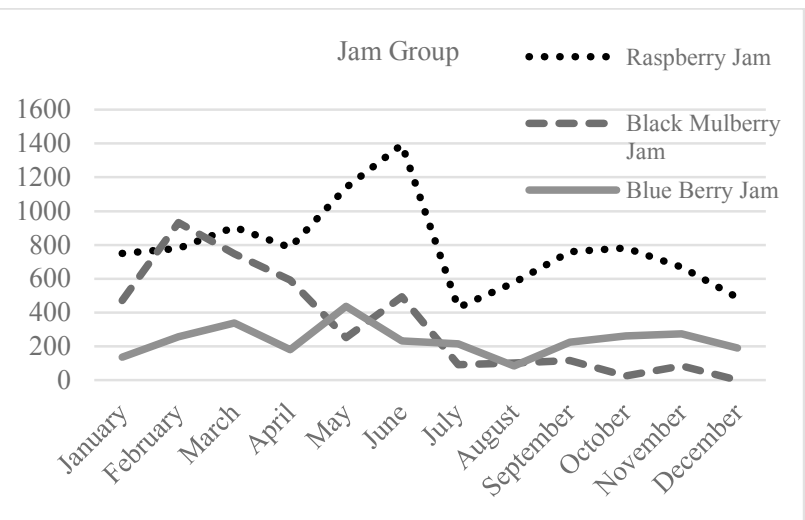

Figure 4 Average sales of Berry Jam group in years

$$
\text { 2013-2015 }
$$

2013-2014 monthly data for every product are tested statistically for normalization using Minitab 17. Results given in Tab. 4 represent that the data are not normal. To test formally for normality, Anderson-Darling, Kolmogorov Smirnov and Ryan Joiner tests are used. The Anderson-Darling test's $p$-value indicates that at $\alpha$ levels, greater than $p$-value, there is evidence that the data do not follow a normal distribution. In Kolmogorov Smirnov and Ryan Joiner, if the $p$-value of the test is less than the chosen $\alpha$-level, the population is not normal.

\begin{tabular}{|l|c|c|c|c|c|c|}
\multicolumn{2}{|c}{ Table 4 Test results for normality } \\
\hline \multirow{2}{*}{$\begin{array}{c}\text { Anderson } \\
\text { Darling }\end{array}$} & \multicolumn{2}{c|}{ Ryan Joiner } & \multicolumn{2}{c|}{$\begin{array}{c}\text { Kolmogorov } \\
\text { Smirnov }\end{array}$} \\
\cline { 2 - 8 } & $p$-Value & AD & $p$-Value & RJ & $p$-Value & KS \\
\hline Lemonade & $<0.005$ & 1.50 & 0.02 & 0.94 & $<0.010$ & 0.25 \\
\hline Black Mulb. Sh. & $<0.005$ & 1.47 & $<0.010$ & 0.93 & $<0.010$ & 0.23 \\
\hline Blue Berry Sh. & $<0.005$ & 1.50 & $<0.010$ & 0.92 & $<0.010$ & 0.27 \\
\hline Currant Sh. & $<0.005$ & 1.25 & 0.017 & 0.94 & $<0.010$ & 0.22 \\
\hline Raspberry Jam & 0.027 & 0.83 & 0.021 & 0.94 & 0.031 & 0.19 \\
\hline Black Mulb. Jam & $<0.005$ & 2.07 & $>0.100$ & 0.97 & $<0.010$ & 0.26 \\
\hline Blue Berry Jam & 0.097 & 0.61 & $>0.100$ & 0.97 & 0.082 & 0.17 \\
\hline
\end{tabular}

The data for each product are then normalized. After normalization, we take the quantitative measures of the forecasting results and seek the most suitable statistical model by comparing the forecasting results with the actual value during year 2015. In order to test the reliability of the forecasting data, we performed regression analysis. Results are given in Tab. 6 as $R^{2}$ and $R^{2}$ (adj.)

$R^{2}$ is a widely known measure of goodness of fit test of a linear model. It ranges from 0 to 1 and the values near to 0 indicate that the model does not fit the given data set. Adjusted $R^{2}$ compares the adjusted part of the model with the basic model. MAPE represents mean absolute percentage error as mentioned in previous sections. According to Lewis, a MAPE result below $10 \%$ is considered a good forecast [15].

In this study, minimum accuracy measures of the forecasting results are selected and highlighted upon 
Trend Analysis, Decomposition and HW methods (see Tab. 5).

The lowest MAPE results obtained are 1.22 for black mulberry jam, 0.47 for lemonade, 1.32 for blueberry sherbet, 1.72 for raspberry jam, 1.53 for currant sherbet, 1.50 for black mulberry sherbet, and finally 2.34 for blueberry jam. These results are valid according to Lewis [15].

Table 5 Results of MAPE after normalization

\begin{tabular}{|l|c|c|c|}
\hline \multirow{2}{*}{\multicolumn{1}{|c|}{ Product Type }} & \multicolumn{3}{c|}{$\begin{array}{c}\text { Accuracy Measure (MAPE) values of } \\
\text { Estimation methods }\end{array}$} \\
\cline { 2 - 4 } & Trend Analysis & Decomposition & HW \\
\hline Black Mulb. J. & 2.77 & 1.22 & 2.29 \\
\hline Lemonade & 2.88 & 0.47 & 0.59 \\
\hline Blue Berry Sh. & 2.46 & 1.32 & 1.50 \\
\hline Raspberry J. & 2.20 & 1.80 & 1.72 \\
\hline Currant Sh. & 2.38 & 0.47 & 1.53 \\
\hline Black Mulb. Sh. & 2.26 & 1.58 & 1.50 \\
\hline Blue Berry Jam & 2.36 & 2.58 & 2.34 \\
\hline
\end{tabular}

However, to see the relation between forecasting value and the actual value, regression analysis is applied. Black mulberry jam, lemonade, blue berry sherbet are described best in multiplicative decomposition method where trend and seasonality are added. Results of $R^{2}$ and $R^{2}$ (adj.) values are given in Tab. 6 respectively as: 0.722 , $0.871,0.754$ and $0.618,0.822,0.618$. Raspberry jam, currant sherbet, black mulberry sherbet and blueberry jam distributions are best described with HW method. $R^{2}$ values are: $0.662,0.673,0,718$ and 0.217 respectively. $R^{2}$ (adj.) values are $0.172,0.153,0.150,0.234$.

Table 6 Results of regression analysis

\begin{tabular}{|l|c|c|}
\hline \multirow{2}{*}{\multicolumn{1}{|c|}{ Product Type }} & \multicolumn{2}{c|}{ Regression Analysis } \\
\cline { 2 - 3 } & $R^{2}$ (adj.) & $R^{2}$ \\
\hline Black Mulb. J. & 0.618 & 0.722 \\
\hline Lemonade & 0.822 & 0.871 \\
\hline Blue Berry Sh. & 0.699 & 0.754 \\
\hline Raspberry J. & 0.494 & 0.662 \\
\hline Currant Sh. & 0.533 & 0.673 \\
\hline Black Mulb. Sh. & 0.612 & 0.718 \\
\hline Blue Berry Jam & 0 & 0.217 \\
\hline
\end{tabular}

Results show that, there is a strong relation between the predicted and actual values except in blueberry jam. We applied Mann-Whitney non-parametric test for blueberry jam in order to test significance of similarity between the predicted and the actual values. Result was significant at 0.1392 and it can be said that the two distributions have a similar characteristic. Under the light of these results, the data assumed to be normal and from the three models, having minimum MAPE results are accepted. The demand of blueberry jam was stable during whole year and seasonal fluctuations are not mentioned as given in Fig. 4. MAPE results of blueberry jam are very near in HW and Trend analysis models. It is known that Trend analysis does not contain seasonality component, so data predicted using Trend analysis model also fit the current situation with a similar accuracy.

Within this context, the two estimation models: Decomposition and HW reached a compatible performance within three methods of time series analysis. MAPE results for these two models show that accuracy values are very near in lemonade, blueberry sherbet, raspberry jam, black mulberry jam and blue berry sherbet. Therefore, it is not possible to say one model is superior to the other.

\section{Conclusion}

The main goal of this study was to propose an optimization model based on demand forecasting approach depending on a comparative study using Trend Analysis, HW's exponential smoothing and Decomposition method of time series forecasting for estimating a realistic future demand.

In order to construct the background required for the model, a demand forecasting approach was necessary. To fulfil this aim, three forecasting methods were utilized and compared with each other to find out the most successful method within the given data set. These methods were chosen according to their performances within certain data sets; the Trend analysis can perform successfully with data with a certain trend, Decomposition method has high performance in 'cyclic' models, and HW method is successful in 'seasonal' models where cyclic data are also existent. After the prediction process, the performances of all the methods were compared and it was observed that the Decomposition and the HW methods were both successful in a trendy-seasonal-cyclic data like our group. The trendy model is only successful for a data group where there is only a trend component.

After this process, regarding the future studies the predicted data will be used in a MILP model including fuzzy demand. The primary objective was to make use of these models in order to develop a decision support system for executives in the F\&B industry.

\section{$6 \quad$ References}

[1] Caruana, A. Step in forecasting with seasonal regression: A case study from the carbonated soft drink market. // Journal of Product and Brand Management. 10, 2(2001), pp. 94102. https://doi.org/10.1108/10610420110388654

[2] Lon-Mu, L.; Siddhartha, B.; Stanley, L. S.; Rong, C.; William, J. L. Data mining on time series: an illustration using fast-food restaurant franchise data. // Computational Statistics \& Data Analysis. 37, 4(2001), pp. 455-476. https://doi.org/10.1016/S0167-9473(01)00014-7

[3] Wassana, S.; Thomas, L.; Chamnein, C.; Nittaya, M. LongTerm Sales Forecasting Using Lee-Carter and Holt-Winters Methods. // The Journal of Applied Business Research. 27, 1 (2011), pp. 87-102.

[4] Veiga, C.; Catapan, A.; Tortato, U.; Silva, W. Demand forecasting in food retail: a comparison between the HoltWinters and ARIMA models. // WSEAS transactions on business and economics. 11, (2014), pp. 608-614.

[5] Barbosa, N. de P.; Christo, E. da S.; Costa, K. A. Demand Forecasting for Production Planning in a Food Company. // ARPN Journal of Engineering and Applied Sciences. 10, 16(2015), pp. 7137-7141.

[6] Arunraj, N. S.; Ahrens, D. A Hybrid seasonal autoregressive integrated moving average and quantile regression for daily food sales forecasting. // International Journal of Production Economics. 170, Part A, (2015), pp. 321-335. 
[7] Makridakis, S.; Andersen, A.; Carbone, R.; Fildes, R.; Hibon, M.; Lewandowski, R.; Newton, J.; Parzen, E.; Winkler, R. The accuracy of extrapolation (time series) methods: results of a forecasting competition. // Journal of Forecasting. 1, 2(1982), pp. 111-153. https://doi.org/10.1002/for.3980010202

[8] Bianchi, M.; Boyle, M.; Hollingsworth, D. A comparison of methods for trend estimation. // Applied Economics Letters. 6, (1999), pp. 103-109. https://doi.org/10.1080/135048599353726

[9] Makridakis, S. G.; Wheelwright, S. C.; Hyndman, R. J. Forecasting: methods and applications. // John Wiley \& Sons Inc., New York, 1998.

[10] Holt, C. C. Forecasting seasonals and trends by exponentially weighted moving averages. // International Journal of Forecasting. 20, 1(2004), pp. 5-10. https://doi.org/10.1016/j.ijforecast.2003.09.015

[11] Winters, P. R. Forecasting sales by exponentially weighted moving averages. // Management Science. 6, (1960), pp. 324-342. https://doi.org/10.1287/mnsc.6.3.324

[12] Yar, M.; Chatfield, C. Prediction intervals for the HoltWinters forecasting procedure. // International Journal of Forecasting. 6, 1(1990), pp. 127-137. https://doi.org/10.1016/0169-2070(90)90103-I

[13] Baker, G. P. Incentive Contracts and Performance Measurement. // The Journal of Political Economy. 100, 3(1992), pp. 598-614. https://doi.org/10.1086/261831

[14] Hyndman, R. J.; Koehler, A. B. Another look at measures of forecast accuracy. // International Journal of Forecasting. 22, 4(2006), pp. 679-688. https://doi.org/10.1016/j.ijforecast.2006.03.001

[15] Lewis, C. D. Demand forecasting and inventory control. John Wiley \& Sons, Inc., New York, 1997.

\section{Authors' addresses}

\section{Güzin Tirkes, Instructor Dr.}

Atılım University, Faculty of Engineering, Dept. of Computer Engineering

Kızılcaşar Mahallesi

06830 Gölbaş1/Ankara, Turkey

E-mail: guzin.tirkes@atilim.edu.tr

\section{Cenk Güray, Assoc. Prof. Dr.}

Yıldırım Beyazıt University

Güvenevler Mahallesi, Cinnah Cd. No. 16, 06690 Çankaya/Ankara, Turkey

E-mail: cenk.guray@gmail.com

\section{Neş'e Çelebi, Prof. Dr.}

Attlım University, Faculty of Engineering, Dept. of Industrial Engineering 06836 İncek/Ankara, Turkey

E-mail: nese.celebi@atilim.edu.tr 